\title{
Arachidonate-Regulated $\mathrm{Ca}^{2+}$ Influx in Human Airway Smooth Muscle
}

\author{
Michael A. Thompson ${ }^{1}$, Y. S. Prakash ${ }^{1,2}$, and Christina M. Pabelick ${ }^{1,2}$ \\ Departments of ${ }^{1}$ Anesthesiology and ${ }^{2}$ Physiology and Biomedical Engineering, Mayo Clinic, Rochester, Minnesota
}

\begin{abstract}
Plasma membrane $\mathrm{Ca}^{2+}$ influx, especially store-operated $\mathrm{Ca}^{2+}$ entry triggered by sarcoplasmic reticulum (SR) $\mathrm{Ca}^{2+}$ release, is a key component of intracellular calcium concentration $\left(\left[\mathrm{Ca}^{2+}\right]_{\mathrm{i}}\right)$ regulation in airway smooth muscle (ASM). Agonist-induced $\mathrm{Ca}^{2+}$ oscillations in ASM that involve both influx and SR mechanisms have been previously demonstrated. In nonexcitable cells, $\left[\mathrm{Ca}^{2+}\right]_{\mathrm{i}}$ oscillations involve $\mathrm{Ca}^{2+}$ influx via arachidonic acid (AA) -stimulated channels, which show similarities to store-operated $\mathrm{Ca}^{2+}$ entry, although their molecular identity remains undetermined. Little is known about AA-regulated $\mathrm{Ca}^{2+}$ channels or their regulation in ASM. In enzymatically dissociated human ASM cells loaded with the $\mathrm{Ca}^{2+}$ indicator, fura-2, AA $(1-10 \mu \mathrm{M})$ triggered $\left[\mathrm{Ca}^{2+}\right]_{\mathrm{i}}$ oscillations that were inhibited by removal of extracellular $\mathrm{Ca}^{2+}$. Other fatty acids, such as the diacylglycerol analog, 1-oleoyl-2-acetylSN-glycerol, oleic acid, and palmitic acid (10 $\mu \mathrm{M}$ each), failed to elicit similar $\left[\mathrm{Ca}^{2+}\right]_{\mathrm{i}}$ responses. Preincubation with $\mathrm{LaCl}_{3}(1 \mu \mathrm{M}$ or $1 \mathrm{mM})$ inhibited AA-induced oscillations. Inhibition of receptor-operated channels (SKF96,365 [10 $\mu \mathrm{M}]$ ), lipoxygenase (zileuton [10 $\mu \mathrm{M}]$ ), or cyclooxygenase (indomethacin $[10 \mu \mathrm{M}]$ ) did not affect oscillation parameters. Inhibition of SR $\mathrm{Ca}^{2+}$ release (ryanodine $[10 \mu \mathrm{M}]$ or inositol 1,4,5-trisphosphate receptor inhibitor, xestospongin $\mathrm{C}[1 \mu \mathrm{M}])$ decreased $\left[\mathrm{Ca}^{2+}\right]_{\mathrm{i}}$ oscillation frequency and amplitude. Small interfering RNA against caveolin-1, stromal interaction
\end{abstract}

molecule 1, or Orai3 (20 $\mathrm{nM}$ each) reduced the frequency and amplitude of AA-induced $\left[\mathrm{Ca}^{2+}\right]_{\mathrm{i}}$ oscillations. In ASM cells derived from individuals with asthma, AA increased oscillation amplitude, but not frequency. These results are highly suggestive of a novel AA-mediated $\mathrm{Ca}^{2+}$-regulatory mechanism in human ASM, reminiscent of agonist-induced oscillations. Given the role of AA in ASM intracellular signaling, especially with inflammation, AA-regulated $\mathrm{Ca}^{2+}$ channels could potentially contribute to increased $\left[\mathrm{Ca}^{2+}\right]_{\mathrm{i}}$ in diseases such asthma.

Keywords: bronchial smooth muscle; calcium; influx; arachidonic acid; sarcoplasmic reticulum

\section{Clinical Relevance}

Arachidonic acid (AA) and its downstream metabolites are important in inflammatory conditions, such as asthma. Here, we present novel data on the expression and properties of a $\mathrm{Ca}^{2+}$ influx pathway regulated by AA in human airway smooth muscle. We believe that the basic science described here is highly relevant to understanding the mechanisms by which agonists and inflammation can enhance $\mathrm{Ca}^{2+}$ in airways and contribute to increased airway contractility.
In human airway smooth muscle (ASM), changes in intracellular calcium concentration $\left(\left[\mathrm{Ca}^{2+}\right]_{\mathrm{i}}\right)$ are mediated by both $\mathrm{Ca}^{2+}$ influx/efflux and $\mathrm{Ca}^{2+}$ release/ reuptake from the sarcoplasmic reticulum (SR) (1-4). We and others have previously shown a variety of $\mathrm{Ca}^{2+}$ influx mechanisms in ASM, including voltage-gated and receptor-operated channels (5-8). In addition, an important influx mechanism that occurs upon SR depletion (e.g., after agonist stimulation) is store-operated $\mathrm{Ca}^{2+}$ entry (SOCE), which aids SR $\mathrm{Ca}^{2+}$ refilling. We and others have demonstrated the presence of SOCE in ASM (9-11). However, one caveat in regard to SOCE is that physiologically relevant agonist concentrations do not necessarily deplete
SR $\mathrm{Ca}^{2+}$ stores, raising the question of whether SOCE normally contributes to $\mathrm{Ca}^{2+}$ influx during agonist-induced airway contractions. We previously demonstrated in porcine ASM that physiologic concentrations of agonists result in the generation of repetitive and stable $\mathrm{Ca}^{2+}$ oscillations characterized by a rapid and transient release of submaximal $\mathrm{Ca}^{2+}$ from

(Received in original form March 24, 2013; accepted in final form January 20, 2014)

This work was supported by National Institutes of Health R01 grants HL090595 (C.M.P.), and HL088029 and HL56470 (Y.S.P.).

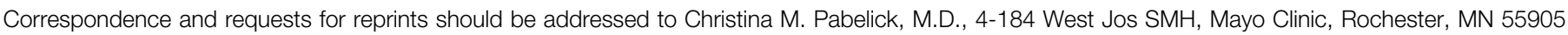
E-mail: pabelick.christina@mayo.edu

Am J Respir Cell Mol Biol Vol 51, Iss 1, pp 68-76, Jul 2014

Copyright (C) 2014 by the American Thoracic Society

Originally Published in Press as DOI: 10.1165/rcmb.2013-01440C on January 28, 2014

Internet address: www.atsjournals.org 
the SR, with concomitant rapid refilling of such intracellular $\mathrm{Ca}^{2+}$ stores via influx $(5,12)$. Such oscillations would prevent full depletion of SR $\mathrm{Ca}^{2+}$ stores, and thus mechanisms that mediate SOCE per se may not be as important in agonist-induced $\left[\mathrm{Ca}^{2+}\right]_{\mathrm{i}}$ oscillations. Accordingly, the question is whether a noncapacitative influx pathway exists that may regulate $\mathrm{Ca}^{2+}$ oscillatory signaling in ASM.

Data in nonexcitable cells show the presence of a novel noncapacitative $\mathrm{Ca}^{2+}$ influx mechanism evoked by arachidonic acid (AA) stimulation (arachidonateregulated $\mathrm{Ca}^{2+}$ [ARC] channels), that is independent of SR store depletion (13-16). Although initially thought to reflect AA effects on a noncapacitative influx pathway, the role of ARC channels is now considered much more diverse, with evidence that these channels are also involved in capacitive $\mathrm{Ca}^{2+}$ entry $(17,18)$. Evidence in nonexcitable cells for this connection comes from data that stromal interaction molecule (STIM) and Orai proteins, which are key regulators of SOCE, can also regulate ARC channels (18). However, what appears to distinguish SOCE from ARC channels is the role of a plasma membrane STIM1 in the regulation of ARC channels $(18,19)$ in contrast to endoplasmic reticulum STIM1 in SOCE. Furthermore, the ARC channel pore is thought to be formed by assembly of three plasma membrane proteins, Orail and two Orai3 subunits (18). There is now substantial evidence that plasma membrane Orail, and STIM1 at the level of the SR, are mediators of SOCE in ASM $(10,11,20-25)$. However, there is currently no information on the role of ARC channels in ASM, their molecular identity, or the mechanisms that may regulate such channels. Accordingly, we hypothesized that ARC channels exist in ASM, and the goal of the present study was to examine their regulation in human ASM cells.

\section{Materials and Methods}

\section{Isolation of Human ASM Cells}

In lung resections of patients undergoing surgery for focal tumors (excluding infectious pathologies, bullae, or widely disseminated cancers), normal third- to sixth-generation human bronchi distant from the tumor were identified and dissected. Patient histories were used to identify subjects with asthma versus those without asthma. Procedures were approved by the Mayo Clinic Institutional Review Board (minimal risk). ASM cells were enzymatically dissociated using papain/ collagenase, and maintained in culture at $37^{\circ} \mathrm{C}\left(5 \% \mathrm{CO}_{2}, 95 \%\right.$ air; less than fifth passage subculture; 4, 24). Dulbecco's modified Eagle's medium (DMEM)/F12 supplemented with $10 \%$ FBS was used until approximately $75 \%$ confluence, with 48-hour serum deprivation before experimentation. Verification of ASM phenotype was performed as previously described (4), using Westerns or immunocytochemistry for presence of smooth muscle actin and myosin, but absence of fibroblast surface protein, and robust $\left[\mathrm{Ca}^{2+}\right]_{\mathrm{i}}$ responses to acetylcholine (ACh).

\section{Western Blot Analysis}

Standard techniques involved SDS-PAGE, transfer to polyvinylidene fluoride membranes, blocking with $5 \%$ milk, overnight incubation at $4^{\circ} \mathrm{C}$ with $1 \mu \mathrm{g} / \mathrm{ml}$ primary antibody, exposure to horseradish peroxidase-conjugated secondary antibodies, and signal detection by enhanced chemiluminescence.

\section{Knockdown by Small Interfering RNA}

Cells were transfected using 20 nM STIM1 small interfering RNA (siRNA; GCCUAUAUCCAGAACCGUtt) (Ambion, Inc., Lafayette, CO), or caveolin-1 siRNA (CUAAACACCUCAACGAUGAUU) or Orai3 siRNA (GCACCUCUUUGCACUCAUG) (Thermo Fisher Scientific, Pittsburgh, PA) using $1 \mu \mathrm{l} / \mathrm{ml}$ lipofectamine in DMEM F/12 lacking FBS. After 6 hours, fresh growth medium was added and cells maintained overnight. Transfection complexes were then aspirated and fresh DMEM/F12 containing 10\% FBS added for an additional 24 hours. Serum deprivation was then maintained for 48 hours, followed by experimentation. Western blots verified specific protein knockdown.

\section{$\left[\mathrm{Ca}^{2+}\right] \mathbf{i}$ Imaging}

Techniques for real-time $\left[\mathrm{Ca}^{2+}\right]_{\mathrm{i}}$ fluorescence imaging of human ASM cells have been previously described $(4,24)$. Fura-2/AM (Invitrogen, Carlsbad, CA) -loaded cells were visualized using a Metafluor-based imaging system on a Nikon microscope (Nikon, Melville, NY). Software regions of interest encompassing substantial intracellular areas were delineated for individual cells (multiple cells per visual field), and fluorescence changes calibrated to $\mathrm{nM} \mathrm{Ca}{ }^{2+}$ using established techniques. Estimated "noise" levels were roughly $10 \mathrm{nM}$, and a valid $\left[\mathrm{Ca}^{2+}\right]_{\mathrm{i}}$ oscillation was considered at greater than 40-nM increase above baseline (measured immediately before initiation of an oscillation). Initial observations suggested temporal summation of oscillations immediately upon AA exposure. For consistency, oscillations were analyzed after 2 minutes of AA exposure, and all valid oscillations considered as individual events. Oscillation frequency was calculated as number of valid events over a defined time period (typically $20 \mathrm{~min}$ ).

\section{Materials}

Chemicals were from Sigma-Aldrich (St. Louis, MO) unless mentioned otherwise. Tissue culture reagents (DMEM F/12, FBS) were from Invitrogen, zileuton from $\mathrm{R} \& \mathrm{D}$ Systems Inc. (Minneapolis, MN), xestospongin $\mathrm{C}(\mathrm{XeC})$ and ryanodine from Millipore Inc. (Billerica, MA), caveolin-1 and secondary antibodies from Santa Cruz Biotechnology, Inc. (Dallas, TX), STIM1 antibody from Novus (Littleton, CO), and Orai3 antibody from Abcam (Cambridge, MA).

\section{Statistical Analysis}

From ASM cells of five different patients (those with asthma or those without), $\left[\mathrm{Ca}^{2+}\right]_{\mathrm{i}}$ experiments were performed using at least 20 cells per patient with three repeats per protocol. Statistically significant $(P<0.05)$ effects of drugs and/or siRNA were evaluated using Student's $t$ test or two-way ANOVA, as appropriate, with Bonferroni's corrections for repeated measures, and Tukey's test for post hoc analyses. Values are expressed as means $( \pm \mathrm{SE})$.

\section{Results}

\section{$\left[\mathrm{Ca}^{2+}\right]_{\mathrm{i}}$ Responses of Human ASM Cells to AA}

In untreated cells (from subjects without asthma), baseline $\left[\mathrm{Ca}^{2+}\right]_{\mathrm{i}}$ levels before any AA exposure ranged between 80 and 120 $\mathrm{nM}$, comparable to our previous reports (5). No spontaneous $\left[\mathrm{Ca}^{2+}\right]_{\mathrm{i}}$ oscillations were observed at baseline. Exposure to AA $(0.1-10 \mu \mathrm{M})$ in the presence of $2 \mathrm{mM}$ extracellular $\mathrm{Ca}^{2+}$ resulted in $\left[\mathrm{Ca}^{2+}\right]_{\mathrm{i}}$ oscillations (Figure 1). Interestingly, there 


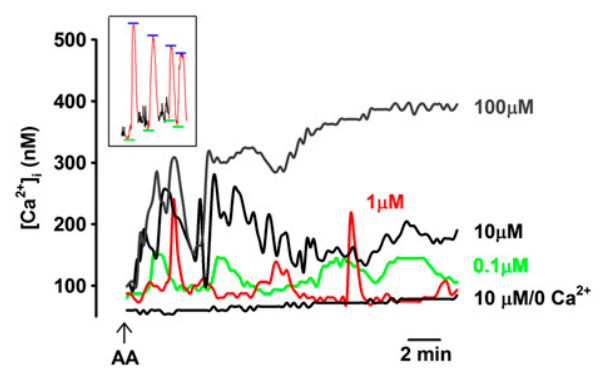

Figure 1. Arachidonic acid (AA) induces intracellular calcium concentration $\left(\left[\mathrm{Ca}^{2+}\right]_{\mathrm{i}}\right)$ oscillations in human airway smooth muscle (ASM). In the presence of $2 \mathrm{mM}$ extracellular $\mathrm{Ca}^{2+}$, exposure of human ASM cells to different concentrations of AA $(0.1-100 \mu \mathrm{M})$ rapidly resulted in $\left[\mathrm{Ca}^{2+}\right]_{i}$ oscillations. Removal of extracellular $\mathrm{Ca}^{2+}$ eliminated these AA-induced $\left[\mathrm{Ca}^{2+}\right]_{i}$ responses. These data suggest the presence of arachidonate-regulated $\mathrm{Ca}^{2+}$ (ARC) channels in human ASM cells, which modulate $\mathrm{Ca}^{2+}$ influx. Inset shows approach to evaluation of baseline $\mathrm{Ca}^{2+}$ (green) and peak $\mathrm{Ca}^{2+}$ (b/ue) for individual oscillations. See Table 1 for summary and statistics.

was no systematic relationship between AA concentration and oscillation features (Table 1; see inset of Figure 1 for evaluation of baseline and peak of valid oscillations). For example, 0.1 and $1 \mu \mathrm{M}$ AA induced slow $\left[\mathrm{Ca}^{2+}\right]_{\mathrm{i}}$ oscillations of comparable amplitude and frequency (Figure 1), whereas $10 \mu \mathrm{M}$ AA showed oscillations at a significantly higher frequency of 0.015 $( \pm 0.005) \mathrm{Hz}$ (which subsided as $\left[\mathrm{Ca}^{2+}\right]_{\mathrm{i}}$ concentrations rose to a higher level; Figure 1; $P<0.05$ compared with lower AA concentrations). Exposure to $10 \mathrm{nM}$ AA did not result in $\left[\mathrm{Ca}^{2+}\right]_{\mathrm{i}}$ oscillations, and inconsistently elevated the baseline $\left[\mathrm{Ca}^{2+}\right]_{\mathrm{i}}$ levels in roughly $10 \%$ of the cells (data not shown; in these cells, average baseline at $20 \mathrm{~min}$ after $10 \mathrm{nM}$ AA was

Table 1. Summary of Intracellular Calcium Concentration Responses of Human Airway Smooth Muscle Cells to Arachidonic Acid

\section{Oscillation Amplitude (nM $\mathrm{Ca}^{2+}$ )}

\section{Oscillation Frequency} $(H z)$

Baseline
$0.1 \mu \mathrm{M}$ AA
$1 \mu \mathrm{M}$ AA
$10 \mu \mathrm{M} \mathrm{AA}$
$100 \mu \mathrm{M} \mathrm{AA}$

No oscillations
\[ \begin{array}{c}101+14 \\ 118 \pm 20 \\ 150 \pm 20^{\star}\end{array} \]
No oscillation, $350 \pm 48$ peak $^{*}$

Definition of abbreviation: AA, arachidonic acid

Values are means \pm SE.

*Significant difference from lower AA concentration $(P<0.05)$.

oscillations were completely abolished (Figure 1, Table 2), suggesting an influxmediated mechanism. This was further confirmed in $\beta$-escin-permeabilized ASM cells (28) in calcium potential ( $\mathrm{pCa}$ ) 7.0, 6.3 , or 6.0 solutions, where $10 \mu \mathrm{M}$ AA did not induce any oscillations (also see below). To investigate whether the AA-induced increase in $\left[\mathrm{Ca}^{2+}\right]_{\mathrm{i}}$ concentration is due to receptor-operated $\mathrm{Ca}^{2+}$ influx, $\left[\mathrm{Ca}^{2+}\right]_{\mathrm{i}}$ responses to $\mathrm{AA}$ were repeated in the presence of $10 \mu \mathrm{M}$ SKF96365 (Figure 3A). However, $10 \mu \mathrm{M}$ AA-induced increases in baseline, average oscillation amplitude, or frequency were unaffected by inhibition of receptor-operated influx (Figure 3, Table 2).

Although the above protocols did not specifically involve depletion of intracellular $\mathrm{Ca}^{2+}$ stores, it was important to determine whether $\mathrm{La}^{3+}$-sensitive influx pathways (reflecting SOCE at lower concentrations [9]) were influenced by AA. Experiments on AA exposure were performed in the presence of $1 \mu \mathrm{M}$ or $1 \mathrm{mM} \mathrm{La}^{3+}$. Oscillation frequency was maintained in the presence of $1 \mu \mathrm{M} \mathrm{La}^{3+}$, but amplitude is decreased, whereas $1 \mathrm{mM} \mathrm{La}^{3+}$ completely abolished oscillations as well as any change in baseline with AA (Figure 3B, Table 2; $P<$ 0.05). Conversely, clamping membrane potential using $60 \mathrm{mM} \mathrm{KCl}$ increased baseline $\mathrm{Ca}^{2+}$ to $230( \pm 49) \mathrm{nM}$, but did not induce any oscillations or substantially influence AA-induced $\left[\mathrm{Ca}^{2+}\right]_{\mathrm{i}}$ oscillations (Table 2 ), suggesting that voltage-gated influx channels were not contributory in this phenomenon.

STIM1 is an important regulatory mechanism in SOCE $(22,23,29)$. We previously demonstrated that STIM1 in human ASM is mostly intracellular (e.g., at SR) and, to a lesser extent, within the plasma membrane (23). However, other investigators $(17,18)$ demonstrated that, in nonexcitable cells, STIM1 is located at the plasma membrane. To further investigate whether STIM1 plays a role in AA effects, AA-induced $\left[\mathrm{Ca}^{2+}\right]_{\mathrm{i}}$ responses were evaluated in ASM cells transfected with STIM1 siRNA (Figure 3C). STIM1 siRNA significantly decreased the frequency and amplitude AA-induced $\left[\mathrm{Ca}^{2+}\right]_{\mathrm{i}}$ oscillations, but did not eliminate them. Baseline $\left[\mathrm{Ca}^{2+}\right]_{\mathrm{i}}$ levels were not significantly influenced by STIM1 siRNA (102 $\pm 31 \mathrm{nM}$ versus $121 \pm 20 \mathrm{nM}$ in lipofectamine controls). In this regard, we previously demonstrated the importance of caveolae and its constituent protein, caveolin-1, in 


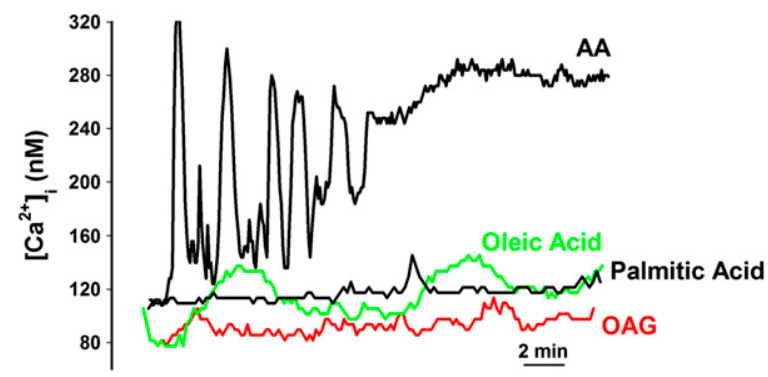

Figure 2. Effect of other fatty acids on $\left[\mathrm{Ca}^{2+}\right]_{\mathrm{i}}$ responses in ASM cells. In contrast to the consistent AA-induced $\left[\mathrm{Ca}^{2+}\right]_{i}$ oscillations, other fatty acids, such as the lipid diacylglycerol analog, 1-oleoyl-2acetyl-SN-glycerol, the saturated fatty acid, palmitic acid, or the monounsaturated oleic acid did not elicit any $\left[\mathrm{Ca}^{2+}\right]_{i}$ oscillations. Indeed, only oleic acid induced any significant increase in $\left[\mathrm{Ca}^{2+}\right]_{i}$ in human ASM cells. These data suggest that the observed $\left[\mathrm{Ca}^{2+}\right]_{\mathrm{i}}$ responses are specific to AA. See Table 2 for summary and statistics.

$\left[\mathrm{Ca}^{2+}\right]_{\mathrm{i}}$ regulation in human ASM (4), further showing that plasma membrane STIM1 is within caveolae (23). Based on the above data showing an effect of STIM1 on AA-induced oscillations, to investigate the role of caveolae, we performed experiments in caveolin-1 siRNA-transfected ASM cells. Compared with lipofectamine control, caveolin-1 siRNA significantly blunted both amplitude and frequency of AA-induced $\left[\mathrm{Ca}^{2+}\right]_{\mathrm{i}}$ oscillations (Figure 3D, Table 2; $P<0.05)$. Baseline $\left[\mathrm{Ca}^{2+}\right]_{\mathrm{i}}$ levels were decreased by caveolin-1 siRNA, but not significantly $(76 \pm 21 \mathrm{nM}$ versus $111 \pm 22$ $\mathrm{nM}$ in lipofectamine controls).

Although the identity of ARC channels is still under investigation, previous work in nonexcitable cells $(30,31)$ suggests plasma membrane Orai3. In human ASM cells transfected with Orai3 siRNA, AA-induced $\left[\mathrm{Ca}^{2+}\right]_{\mathrm{i}}$ oscillation frequency was significantly reduced (Figure 3E, Table 2; $P<0.05$ ).

However, there was no significant effect on oscillation amplitude, or baseline $\mathrm{Ca}^{2+}$ levels.

For STIM1, caveolin-1, and Orai3 siRNA experiments, nonsense siRNAs did not

Table 2. Characterization of Arachidonic Acid-Regulated $\mathrm{Ca}^{2+}$ Channels in Human Airway Smooth Muscle Cells

\section{Oscillation Frequency} $(\mathrm{Hz})$

\section{Oscillation Amplitude} $\left(\right.$ (nM $\left.\mathrm{Ca}^{2+}\right)$

$178 \pm 19$
No oscillations
No oscillations
$33 \pm 9^{\star}$
$42 \pm 7^{\star}$
No oscillations
$182 \pm 12$
$110 \pm 17^{\star}$
$33 \pm 9^{\star}$
$132 \pm 33$
$155 \pm 15^{\star}$
$138+40$
$91 \pm 9^{\dagger}$
$101 \pm 17^{\dagger}$
$117 \pm 22$
$130 \pm 10$
$122 \pm 15$
$301 \pm 90^{\star}$

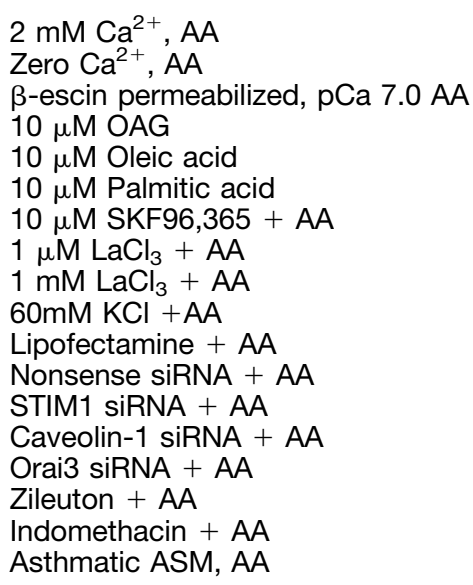

Definition of abbreviations: AA, arachidonic acid; ASM, airway smooth muscle; OAG, 1-oleoyl-2acetyl-SN-glycerol; pCa, calcium potential; siRNA, small interfering RNA; STIM, stromal interaction molecule

Values are means \pm SE. All AA experiments were at 10- $\mu \mathrm{M}$ concentration.

*Significant difference from $10 \mu \mathrm{M}$ AA $(P<0.05)$.

${ }^{\dagger}$ Significant difference from $10 \mu \mathrm{M}$ AA effects on lipofectamine-transfected cells $(P<0.05)$. substantially influence AA-induced $\left[\mathrm{Ca}^{2+}\right]_{\mathrm{i}}$ oscillations, nor did lipofectamine alone (vehicle control). Western analysis confirmed substantial knockdown of these three proteins by the specific siRNAs, with lack of effect of the nonsense siRNAs (Figure 3F).

AA can serve as a substrate for the lipoxygenase (LOX), cyclo-oxygenase (COX), and CYP450 pathways, which produce metabolites, such as leukotrienes, prostaglandins, epoxyeicosatrienoic acid, and hydroxyeicosatetraenoic acid. These metabolites can induce inflammation and alter $\mathrm{Ca}^{2+}$ influx (32). Additional experiments were performed in the presence of the LOX inhibitor, zileuton $(10 \mu \mathrm{M})$, and the COX inhibitor, indomethacin $(10 \mu \mathrm{M}$; Figure 4). Cells were incubated with inhibitor 15 minutes before AA. Neither inhibitor showed a significant effect on AA-induced $\left[\mathrm{Ca}^{2+}\right]_{\mathrm{i}}$ oscillations (Figure 4, Table 2; $P<0.05$ ). Based on these data showing lack of effect of LOX or COX inhibition on AA-induced oscillations, we did not explore the potential role of AA metabolites further.

We previously demonstrated that agonist-induced $\left[\mathrm{Ca}^{2+}\right]_{\mathrm{i}}$ oscillations represent repetitive $\mathrm{SR} \mathrm{Ca}^{2+}$ release via ryanodine receptor (RyR) channels or inositol 1,4,5-trisphosphate $\left(\mathrm{IP}_{3}\right)$ receptor channels $(5,12)$. To determine whether AA-induced $\left[\mathrm{Ca}^{2+}\right]_{\mathrm{i}}$ oscillations also represented such repetitive $\mathrm{Ca}^{2+}$ release from intracellular stores, we repeated experiments in the presence of high, blocking concentrations of the RyR modulator, ryanodine $(10 \mu \mathrm{M})$ or the $\mathrm{IP}_{3}$ receptor blocker, $\mathrm{XeC}(1 \mu \mathrm{M}$; Figure 5$)$. In the presence of either ryanodine or $\mathrm{XeC}$, AA-induced $\left[\mathrm{Ca}^{2+}\right]_{\mathrm{i}}$ oscillations were abolished, and only minimally elevated $\left[\mathrm{Ca}^{2+}\right]_{\mathrm{i}}$ levels were observed (Figure 5), demonstrating that AA effects do involve $\mathrm{SR} \mathrm{Ca}^{2+}$ release, but likely due to indirect effects on the SR resulting from $\mathrm{Ca}^{2+}$ influx. This was supported by the lack of $\left[\mathrm{Ca}^{2+}\right]_{\mathrm{i}}$ oscillations in the absence of extracellular $\mathrm{Ca}^{2+}$ (Figure 1) as well as in $\beta$-escin-permeabilized ASM cells in pCa 7.0 (corresponding to baseline $\mathrm{Ca}^{2+}$ of $\sim 100$ nM; Figure 5). A similar lack of effect of AA was observed in permeabilized ASM cells in pCa $6.3(\sim 500 \mathrm{nM}$; data not shown).

\section{AA Effects in ASM Cells from Subjects with Asthma}

In general, baseline $\left[\mathrm{Ca}^{2+}\right]_{\mathrm{i}}$ levels before AA exposure were not higher in ASM cells 

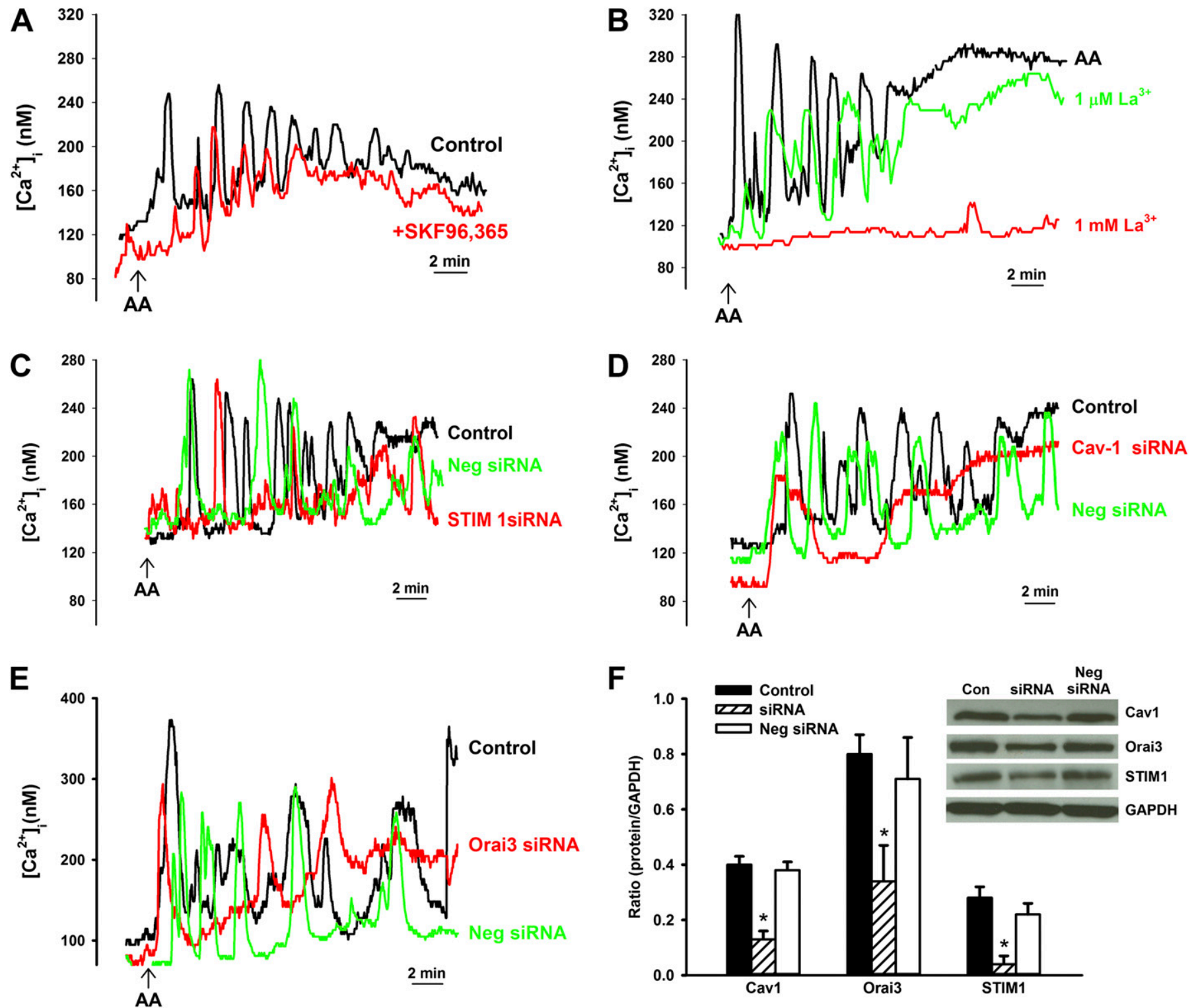

Figure 3. Mechanisms of AA-induced $\mathrm{Ca}^{2+}$ influx. (A) Role of receptor-operated $\mathrm{Ca}^{2+}$ entry in $\mathrm{AA}$-induced $\mathrm{Ca}^{2+}$ influx. In the presence of the receptoroperated channel inhibitor, SKF96365 $(10 \mu \mathrm{M})$, AA-induced $\left[\mathrm{Ca}^{2+}\right]_{\mathrm{i}}$ responses were not significantly altered, suggesting that the observed $\mathrm{Ca}^{2+}$ influx was not via this mechanism. (B) Role of store-operated $\mathrm{Ca}^{2+}$ entry (SOCE) in AA-induced $\mathrm{Ca}^{2+}$ influx. La ${ }^{3+}(1 \mu \mathrm{M}$; which inhibits SOCE) slightly decreased the amplitude of $A A$-induced $\left[\mathrm{Ca}^{2+}\right]_{i}$ oscillations, but did not affect oscillation frequency. In contrast, $1 \mathrm{mM} \mathrm{La}^{3+}$ completely eliminated $\left[\mathrm{Ca}^{2+}\right]_{\mathrm{i}}$ responses, suggesting that the observed influx is unlikely to be SOCE, especially because sarcoplasmic reticulum (SR) stores were not depleted during these experiments. (C) Role of stromal interaction molecule (STIM) 1 in AA-induced $\left[\mathrm{Ca}^{2+}\right]_{i}$ responses. In the presence of STIM1 small interfering RNA (siRNA), AA-induced elevations in $\left[\mathrm{Ca}^{2+}\right]_{i}$ levels were reduced and $\left[\mathrm{Ca}^{2+}\right]_{i}$ oscillations decreased compared with lipofectamine (vehicle) control, whereas negative siRNA was without effect. These data suggest that STIM1 modulates AA-induced $\left[\mathrm{Ca}^{2+}\right]_{\mathrm{i}}$ responses. (D) Role of caveolae/caveolin-1 in AA-induced $\left[\mathrm{Ca}^{2+}\right]_{i}$ responses. Suppression of caveolin-1 using siRNA eliminated AA-induced $\left[\mathrm{Ca}^{2+}\right]_{i}$ oscillations, whereas lipofectamine or negative siRNA were without effect. These data suggest that caveolin-1 modulates AA-induced $\mathrm{Ca}^{2+}$ influx in human ASM. (E) Role of Orai3 on AA-induced $\left[\mathrm{Ca}^{2+}\right]_{i}$ responses. Orai3 siRNA reduced the frequency of $A A$-induced $\left[\mathrm{Ca}^{2+}\right]_{i}$ oscillations and slightly altered the amplitudes of $\left[\mathrm{Ca}^{2+}\right]_{l}$ compared with lipofectamine or negative siRNA. These data suggest a role for Orai 3 in modulating AA-induced $\left[\mathrm{Ca}^{2+}\right]_{i}$ responses. $(F)$ Western analysis confirmed siRNA knockdown of STIM1, caveolin-1, and Orai3, and lack of effect of negative siRNA. See Table 2 for summary and statistics of Ca ${ }^{2+}$. ${ }^{*}$ Significant siRNA effect $(P<0.05)$. Cav1, caveolin-1; Con, control; GAPDH, glyceraldehyde 3-phosphate dehydrogenase; Neg, negative.

from subjects with moderate asthma (defined by forced expiratory volume in 1 second/forced vital capacity, daily use of short-acting bronchodilator). However, exposure of ASM cells from subjects with asthma to $10 \mu \mathrm{M}$ AA resulted in higher oscillation amplitude compared with cells from subjects without asthma, but there was no difference in oscillation frequency (Figure 6, Table 2). Removal of extracellular $\mathrm{Ca}^{2+}$ prevented $\left[\mathrm{Ca}^{2+}\right]_{\mathrm{i}}$ oscillations as with nonasthmatic cells. 


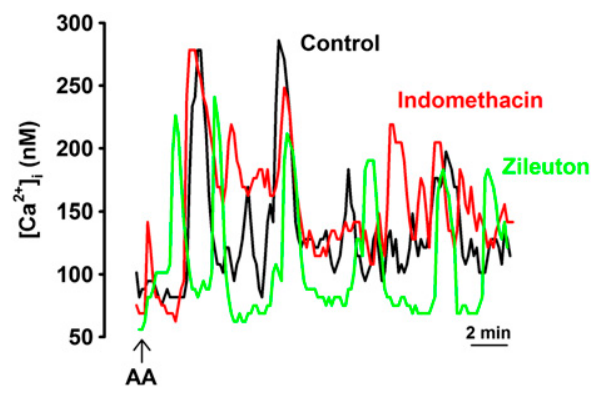

Figure 4. Role of lipoxygenase (LOX) and cyclooxygenase (COX) pathways in AA-mediated $\left[\mathrm{Ca}^{2+}\right]_{i}$ responses. AA can serve as a substrate for the LOX and COX pathways that produce metabolites (leukotrienes, prostaglandins, and prostacyclins), which can mediate inflammation and alter $\mathrm{Ca}^{2+}$ influx. Inhibitors of LOX (zileuton) and COX (indomethacin) did not significantly influence $10 \mu \mathrm{M}$ AA-induced $\left[\mathrm{Ca}^{2+}\right]_{i}$ oscillations, suggesting that ARC channels are specifically modulated by AA, and not by products downstream to AA. See Table 2 for summary and statistics.

\section{Discussion}

$\mathrm{Ca}^{2+}$ influx through a variety of mechanisms is a key aspect of $\left[\mathrm{Ca}^{2+}\right]_{\mathrm{i}}$ regulation in ASM. In this regard, capacitative $\mathrm{Ca}^{2+}$ entry in response to intracellular store depletion (i.e., SOCE) is an important mechanism in ASM (9-11, 25). However, there is increasing evidence in nonexcitable cells for an additional noncapacitative $\mathrm{Ca}^{2+}$ influx mechanism regulated by AA $(13,33)$. What is less clear is the molecular identity of such ARC channels, with data in other cell types suggesting a role for Orai proteins that are also involved in SOCE. The data in the current study strongly suggest the existence of ARC channels in human ASM, and such channels involve $\mathrm{Ca}^{2+}$ influx and are mediated via Orai3 proteins. However, other modulatory mechanisms, such as STIM1 and caveolin-1, also appear to be important. Although AA generation is known to occur in human ASM in response to agonist stimulation and in inflammation, our novel results suggest that such AA, by itself, may act through a plasma membrane caveolar mechanism, perhaps Orai3 with a role for plasma membrane STIM1, to induce $\left[\mathrm{Ca}^{2+}\right]_{\mathrm{i}}$ oscillations (Figure 7), akin to those induced by agonists, such as ACh (5). Such AA-induced oscillations appear to involve intracellular $\mathrm{Ca}^{2+}$ release as well, and may thus also partly result from storeoperated mechanisms (but not receptoroperated influx). Furthermore, AA-induced $\left[\mathrm{Ca}^{2+}\right]_{\mathrm{i}}$ responses appear to be enhanced in asthmatic ASM. Overall, these data indicate that ARC channels may be an important $\mathrm{Ca}^{2+}$-regulatory mechanism in human ASM, and may contribute to modulation of $\left[\mathrm{Ca}^{2+}\right]_{\mathrm{i}}$ during agonist stimulation or with inflammation.

Although ARC channels have been demonstrated in a variety of nonexcitable cells $(16,34)$, their existence and role in ASM has not been studied. In terms of smooth muscle, a previous study reported AA-sensitive $\mathrm{Ca}^{2+}$ influx pathways in A7R5 vascular smooth muscle cells (35). In the current study, we demonstrate that concentrations of AA in the micromolar range induce $\left[\mathrm{Ca}^{2+}\right]_{\mathrm{i}}$ responses, including oscillations. This effect is completely abolished upon removal of extracellular $\mathrm{Ca}^{2+}$, demonstrating the importance of $\mathrm{Ca}^{2+}$ influx in responses of ASM cells to AA. An interesting observation was that

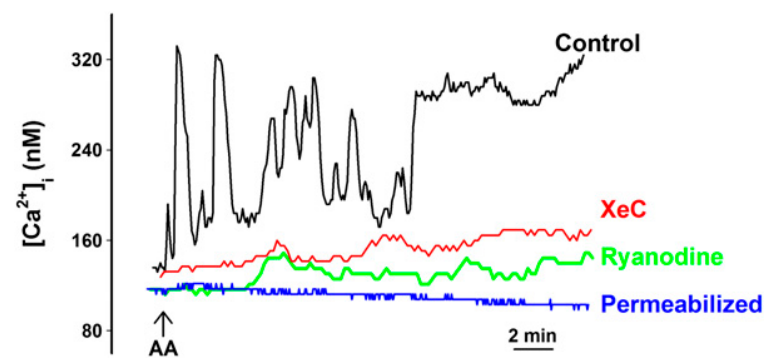

Figure 5. Role of $\mathrm{SR} \mathrm{Ca}^{2+}$ release in $\mathrm{AA}$-induced $\mathrm{Ca}^{2+}$ oscillations. The presence of the cellpermeant inositol 1,4,5-trisphosphate $\left(\mathrm{IP}_{3}\right)$ receptor blocker, xestospongin $\mathrm{C}(\mathrm{XeC} ; 1 \mu \mathrm{M})$ or blocking concentrations of ryanodine $(10 \mu \mathrm{M})$ eliminated all $\left[\mathrm{Ca}^{2+}\right]_{i}$ oscillations, with only slight increases in $\left[\mathrm{Ca}^{2+}\right]_{\mathrm{i}}$ levels. Separately, in $\beta$-escin-permeabilized cells in a pCa of 7.0 (corresponding to $100 \mathrm{nM}$ $\mathrm{Ca}^{2+}$ as reflected by baseline $\left.\mathrm{Ca}^{2+}\right)$, AA was without effect on $\left[\mathrm{Ca}^{2+}\right]_{\mathrm{i}}$, indicating that $\mathrm{AA}$-induced $\left[\mathrm{Ca}^{2+}\right]_{\mathrm{i}}$ responses only indirectly modulate SR $\mathrm{Ca}^{2+}$ release. See Table 2 for summary and statistics.

there was no clear relationship between AA concentration and the amplitude or frequency of $\left[\mathrm{Ca}^{2+}\right]_{\mathrm{i}}$ oscillations. Furthermore, $\left[\mathrm{Ca}^{2+}\right]_{\mathrm{i}}$ responsiveness to AA in terms of oscillations seems to occur over a narrow concentration range ( $>0.1$ to $<100 \mu \mathrm{M}$ ), and involves just frequency modulation (Table 1). In this regard, it may be important to consider the appropriate concentrations of AA to examine. There is currently no information on levels in ASM per se. However, published literature (e.g., Ref. 27) suggests that the concentration of free AA in resting cells is "low." Esterified (presumably inactive) AA levels in platelets are in the 5-mM range, with plasma membrane concentrations being even higher. Thus, even small amounts of release of this AA would provide $50 \mu \mathrm{M}$. Free AA levels in tissues or cells has been reported to be anywhere from $0.5-100 \mu \mathrm{M}$, and cells are thought to respond in the $1-10 \mu \mathrm{M}$ AA range. Therefore, our use of $10 \mu \mathrm{M} \mathrm{AA}$ is consistent with previous data.

Although the underlying reasons for the lack of a classical dose-response curve to AA are not entirely clear, oscillations only at higher AA concentrations may represent a threshold within ASM cells to prevent inappropriate $\left[\mathrm{Ca}^{2+}\right]_{i}$ responses to AA. Accordingly, the higher $\left[\mathrm{Ca}^{2+}\right]_{\mathrm{i}}$ responses to AA in asthmatic ASM may reflect a change in this threshold, contributing to an overall increase in $\left[\mathrm{Ca}^{2+}\right]_{i}$ that does occur in asthmatic ASM cells. Alternatively, because ARC channels are regulated by AA, but do not necessarily involve receptorcoupled mechanisms, perhaps a classical dose-response cannot be expected. Furthermore, it may be necessary to examine the precise relationships between AA-induced regulatory mechanisms in ASM, and the sensitivity of putative ARC channel elements, such as Orai3 or STIM1, to these mechanisms: topics for future studies.

Mignen and colleagues (36) demonstrated in HEK293, COS, and HeLa cells the existence and high selectivity of ARC channels for $\mathrm{Ca}^{2+}$ as well as AA itself. In comparison to AA, other monounsaturated and saturated fatty acids had no effect. In the current study using human ASM, we demonstrated that, in comparison to AA, the diacylglycerol analog, OAG, oleic acid, and palmitic acid had minimal effects on $\left[\mathrm{Ca}^{2+}\right]_{\mathrm{i}}$, and only occasionally induced $\left[\mathrm{Ca}^{2+}\right]_{\mathrm{i}}$ oscillations. 


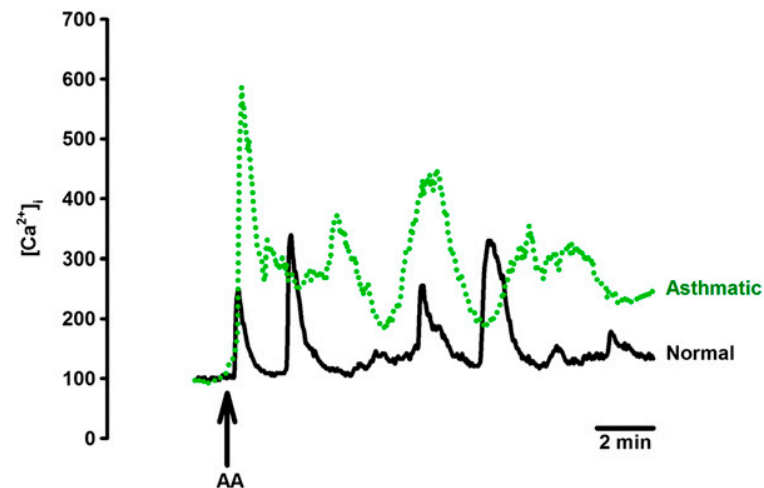

Figure 6. Effect of AA on $\left[\mathrm{Ca}^{2+}\right]_{i}$ in asthmatic ASM. In isolated ASM cells from patients with moderate asthma, $10 \mu \mathrm{M}$ AA induced $\left[\mathrm{Ca}^{2+}\right]_{i}$ oscillations of higher amplitude compared with nonasthmatic ASM cells. However, oscillation frequency was not different. See Table 2 for summary and statistics.

Furthermore, inhibition of LOX and COX pathways downstream to AA were without effect. These novel data are highly suggestive of an AA-specific influx pathway in ASM similar to that in nonexcitable cells.

Intracellular $\mathrm{Ca}^{2+}$ regulation in ASM involves interplay between plasma membrane $\mathrm{Ca}^{2+}$ influx/efflux and SR $\mathrm{Ca}^{2+}$ release/reuptake (1-4). Accordingly, overall $\left[\mathrm{Ca}^{2+}\right]_{\mathrm{i}}$ regulation may be dependent on both physical proximity of regulatory elements as well as changes in $\mathrm{Ca}^{2+}$ gradients and fluxes induced by these regulatory elements. In this regard, our

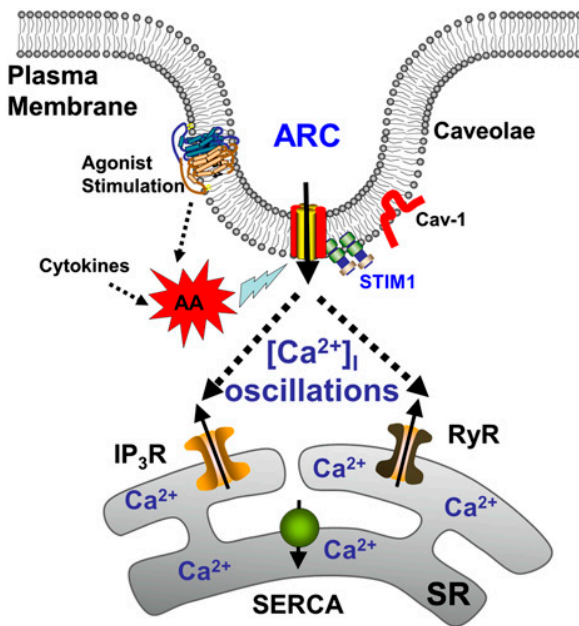

Figure 7. Proposed model of ARC channels in human ASM. Regardless of the source (agonistor cytokine-induced production), AA activates plasma membrane ARC channels that are within caveolae. Such activation is facilitated by plasma membrane STIM1, and involves repeated SR $\mathrm{Ca}^{2+}$ release. $I \mathrm{P}_{3} \mathrm{R}, \mathrm{IP}$ receptor; RyR, ryanodine receptor; SERCA, sarco/endoplasmic reticulum calcium ATPase. previous data, showing that agonists, such as $\mathrm{ACh}$, induce repetitive $\left[\mathrm{Ca}^{2+}\right]_{\mathrm{i}}$ oscillations representing cyclical SR $\mathrm{Ca}^{2+}$ release/reuptake with a supportive role for $\mathrm{Ca}^{2+}$ influx, are significant. Here, in addition to voltage-operated and receptoroperated $\mathrm{Ca}^{2+}$ influx, we and others have demonstrated the importance of SOCE in ASM (9-11). What is less clear is whether SOCE per se is important in agonistinduced $\left[\mathrm{Ca}^{2+}\right]_{\mathrm{i}}$ oscillations, because store depletion may or may not occur, especially at lower agonist concentration. In this regard, data from nonexcitable cells show that, in contrast to SOCE, which relies on high agonist concentrations and almost complete SR $\mathrm{Ca}^{2+}$ depletion, ARC channel activity depends on low agonist concentrations $(16,34)$. Accordingly, the relevance of ARC channels in ASM cells may lie in providing a non-SOCE $\mathrm{Ca}^{2+}$ influx pathway after submaximal agonist stimulation typically associated with $\left[\mathrm{Ca}^{2+}\right]_{\mathrm{i}}$ oscillations $(37,38)$. Here, the higher $\left[\mathrm{Ca}^{2+}\right]_{\mathrm{i}}$ responses of asthmatic ASM cells to AA may contribute to the higher $\left[\mathrm{Ca}^{2+}\right]_{\mathrm{i}}$ responses to bronchoconstrictor agonists in such cells.

Although it is clear that ARC channels involve $\mathrm{Ca}^{2+}$ influx (demonstrated by the abolition of responses to AA in zero extracellular $\mathrm{Ca}^{2+}$, by high levels of $\mathrm{LaCl}_{3}$, and the lack of responses to AA in $\beta$-escin-permeabilized cells), given the lack of specific pharmacological inhibitors, and only limited data suggesting actual molecular identities of these channels, it is difficult to state with complete confidence that the AA-sensitive $\left[\mathrm{Ca}^{2+}\right]_{\mathrm{i}}$ responses observed in ASM cells in this study truly present ARC channels per se. However, data included in our study are generally consistent with previous work in nonexcitable cells, and indirectly suggest that ARC channels do exist in ASM. For example, because ARC channel activity can depend on agonist concentration, receptoroperated $\mathrm{Ca}^{2+}$ channels need to be eliminated as potential confounders. Our data showing lack of effect of the receptoroperated $\mathrm{Ca}^{2+}$ channel inhibitor, SKF96365 (consistent with data in nonexcitable cells [34]), would indeed eliminate this possibility. Another potential confounder is channels that mediate SOCE that occurs in response to $\mathrm{SR} \mathrm{Ca}^{2+}$ depletion, thus serving as an important mechanism for SR refilling $(9,39-42)$. In nonexcitable cells, it has been shown that $\mathrm{Ca}^{2+}$ influx switches from ARC channels at low agonist concentrations to SOCE at higher agonist concentrations (16). Previous studies in ASM demonstrate SOCE is triggered by SR $\mathrm{Ca}^{2+}$ release via both $\mathrm{IP}_{3}$ receptor and RyR channels, and is modulated by agonists $(9,43)$. However, the sensing or activation mechanisms for SOCE, initially thought to involve transient receptor potential channels, including in $\operatorname{ASM}(4,43)$, have been shown to involve STIM1 at the level of the SR and the plasma membrane Orail $(44,45)$. In this regard, our data (and those in nonexcitable cells) show that AA-mediated $\left[\mathrm{Ca}^{2+}\right]_{\mathrm{i}}$ responses do not represent STIM1/Orail-mediated SOCE. However, it is also important to note that both STIM and Orai are highly relevant to ARC channels. The Orai family of proteins (Orai1-3) is thought to be the "pore-forming" unit in the plasma membrane that interacts with the $\mathrm{C}$ terminus of STIM1 to initiate SOCE or to activate ARC channels (46). Shuttleworth (18) and Thompson and Shuttleworth (19) demonstrated in nonexcitable cells a role for plasma membrane STIM1 in ARC channels. This is in contrast to SOCE, where SR STIM1 appears to be important. We previously found that SR STIM1 is involved in ASM SOCE (23), but found only small amounts of plasma membrane STIM1. Our finding that AA-induced $\left[\mathrm{Ca}^{2+}\right]_{\mathrm{i}}$ responses are substantially blunted in the presence of STIM1 siRNA now suggests a role for the latter. In addition, the units required for the assembly of SOCE channels in comparison to ARC channels are different (18). Whereas Orail is particularly important in SOCE (including in ASM), the ARC channel pore is thought to be formed by assembly of three Orai1 
and two Orai3 subunits (18). Our observation that knockdown of Orai3 via siRNA results in a $50 \%$ decrease in AA-induced $\left[\mathrm{Ca}^{2+}\right]_{i}$ oscillations is entirely consistent with this scenario in human ASM. Thus, our data overall underline the existence of ARC channels in human ASM.

A novel aspect of our study is the finding that plasma membrane caveolae are important for ARC channels in human ASM. Caveolae are specialized forms of lipid rafts found in most cells types. Previous studies by our group and others $(4,47,48)$ suggest that caveolae contain a variety of proteins that are important for $\left[\mathrm{Ca}^{2+}\right]_{i}$ signaling in ASM, including STIM1 and Orai proteins. Our data in this study, showing that caveolin-1 substantially blunts AA responses, suggests that the mechanisms that involve ARC channel activity, likely STIM1, Orai1, and Orai3, are located within caveolae. Thus, caveolae may facilitate interactions between plasma membrane STIM1 and Orai3, and thus be an important modulator of AA-induced $\mathrm{Ca}^{2+}$ influx.

An interesting aspect of AA-induced $\left[\mathrm{Ca}^{2+}\right]_{\mathrm{i}}$ oscillations is their inhibition by blocking of SR $\mathrm{Ca}^{2+}$ release channels via ryanodine and XeC. Although ARC channels are clearly an influx mechanism, such influx appears to trigger SR $\mathrm{Ca}^{2+}$ release, perhaps by the well known $\mathrm{Ca}^{2+}$ induced $\mathrm{Ca}^{2+}$ release mechanism. What is less clear is whether any intermediate signaling pathways are involved.

Furthermore, it is not clear whether AA or its metabolites separately affect $\mathrm{IP}_{3}$ channel or RyR to alter their opening probability or sensitivity to $\left[\mathrm{Ca}^{2+}\right]_{\mathrm{i}}$. Although AA effects on $\mathrm{SR} \mathrm{Ca}^{2+}$ release channels are possible, the lack of AA-induced $\left[\mathrm{Ca}^{2+}\right]_{\mathrm{i}}$ oscillations in $\beta$-escin-permeabilized cells would suggest otherwise.

In addition to effects on mechanisms, such as Orai3, which may be part of the ARC channel pore, AA itself is known to activate a number of channels, particularly a range of $\mathrm{K}^{+}$channels (49), with both membrane depolarization and hyperpolarization being possible depending on whether AA or its metabolites are involved. Although we did not specifically examine the role of $\mathrm{K}^{+}$ channels in this study, the observation that clamping membrane potential with $60 \mathrm{mM}$ $\mathrm{KCl}$ did not produce spontaneous $\left[\mathrm{Ca}^{2+}\right]_{\mathrm{i}}$ oscillations or influence oscillations induced by AA would suggest that even if $\mathrm{K}^{+}$channels were affected by AA, membrane potential itself may not influence ARC channel regulation. With regard to AA metabolites, the downstream CYP450, COX, and LOX pathways can produce a number of metabolites that may potentially mediate AA effects on $\left[\mathrm{Ca}^{2+}\right]_{\mathrm{i}}$. However, our observations that inhibition of COX or LOX did not substantially influence AA-induced oscillations would suggest that metabolites of at least these two enzymes are likely not involved. Lack of enhanced AA effects in the presence of inhibitors of COX or LOX would further suggest that diversion of AA to the CYP450 pathway and resultant metabolites also may not play a role.

The relevance of AA-induced $\left[\mathrm{Ca}^{2+}\right]_{\mathrm{i}}$ responses and ARC channels in ASM lies in the potential role of this regulatory mechanism in inflammatory airway diseases, such as asthma, where AA- mediated pathways are thought to be important (50). Accordingly, the limited but interesting data that asthmatic ASM cells have a higher amplitude of $\left[\mathrm{Ca}^{2+}\right]_{\mathrm{i}}$ responses to AA raise the question of whether ARC channels are potentially contributory to increased $\left[\mathrm{Ca}^{2+}\right]_{i}$ in asthmatic ASM. Although the mechanisms for such up-regulation were beyond the scope of this study, enhanced Orai3 expression (or activation) may be involved, and would be consistent with previous findings that related mechanisms, such as STIM1, Orai1, and even caveolin-1, are upregulated in human ASM after inflammation $(11,24,25)$. Furthermore, inflammation can result in enhanced expression of SR $\mathrm{Ca}^{2+}$ proteins and functionality, and AA-induced influx could produce greater $\mathrm{SR} \mathrm{Ca}^{2+}$ responses, leading to greater contraction.

In conclusion, our study demonstrates the existence of ARC channels in human ASM similar to that in nonexcitable cells. The relevance of ARC channels in ASM lies in its potential contribution to $\mathrm{Ca}^{2+}$ influx during agonist stimulation, when SR store depletion may not occur, thus allowing a non-SOCE pathway for $\mathrm{Ca}^{2+}$ influx to replenish stores. Given the generation of AA after agonist stimulation and inflammation, ARC channels may be particularly important in contributing to the elevated $\left[\mathrm{Ca}^{2+}\right]_{i}$ levels observed in inflamed/asthmatic ASM, and thus to increased airway contractility.

Author disclosures are available with the text of this article at www.atsjournals.org.

\section{References}

1. Hirota $S$, Helli $P$, Janssen LJ. Ionic mechanisms and $\mathrm{Ca}^{2+}$ handling in airway smooth muscle. Eur Respir J 2007;30:114-133.

2. Pabelick CM, Sieck GC, Prakash YS. Invited review: significance of spatial and temporal heterogeneity of calcium transients in smooth muscle. J Appl Physiol (1985) 2001;91:488-496.

3. Sathish V, Thompson MA, Bailey JP, Pabelick CM, Prakash YS, Sieck GC. Effect of proinflammatory cytokines on regulation of sarcoplasmic reticulum $\mathrm{Ca}^{2+}$ reuptake in human airway smooth muscle. $\mathrm{Am} \mathrm{J}$ Physiol Lung Cell Mol Physiol 2009;297:L26-L34.

4. Prakash YS, Thompson MA, Vaa B, Matabdin I, Peterson TE, He T, Pabelick CM. Caveolins and intracellular calcium regulation in human airway smooth muscle. Am J Physiol Lung Cell Mol Physiol 2007;293: L1118-L1126.

5. Prakash YS, Kannan MS, Sieck GC. Regulation of intracellular calcium oscillations in porcine tracheal smooth muscle cells. Am J Physio 1997;272:C966-C975.

6. Townsend EA, Thompson MA, Pabelick CM, Prakash YS. Rapid effects of estrogen on intracellular $\mathrm{Ca}^{2+}$ regulation in human airway smooth muscle. Am J Physiol Lung Cell Mol Physiol 2010;298:L521-L530.
7. Liu QH, Zheng YM, Korde AS, Yadav VR, Rathore R, Wess J, Wang YX. Membrane depolarization causes a direct activation of $\mathrm{G}$ protein-coupled receptors leading to local $\mathrm{Ca}^{2+}$ release in smooth muscle. Proc Natl Acad Sci USA 2009;106:11418-11423.

8. Berridge MJ. Smooth muscle cell calcium activation mechanisms. J Physiol 2008;586:5047-5061.

9. Ay B, Prakash YS, Pabelick CM, Sieck GC. Store-operated $\mathrm{Ca}^{2+}$ entry in porcine airway smooth muscle. Am J Physiol Lung Cell Mol Physiol 2004;286:L909-L917.

10. Peel SE, Liu B, Hall IP. A key role for STIM1 in store operated calcium channel activation in airway smooth muscle. Respir Res 2006;7:119.

11. Peel SE, Liu B, Hall IP. ORAI and store-operated calcium influx in human airway smooth muscle cells. Am J Respir Cell Mol Biol 2008;38:744-749.

12. Prakash YS, Pabelick CM, Kannan MS, Sieck GC. Spatial and temporal aspects of $\mathrm{ACh}$-induced $\left[\mathrm{Ca}^{2+}\right]_{\mathrm{i}}$ oscillations in porcine tracheal smooth muscle. Cell Calcium 2000;27:153-162.

13. Shuttleworth TJ. Arachidonic acid, ARC channels, and Orai proteins. Cell Calcium 2009;45:602-610.

14. Shuttleworth TJ, Thompson JL, Mignen O. ARC channels: a novel pathway for receptor-activated calcium entry. Physiology (Bethesda) 2004;19:355-361. 
15. Mignen O, Shuttleworth TJ. I(ARC), a novel arachidonate-regulated, noncapacitative $\mathrm{Ca}(2+)$ entry channel. J Biol Chem 2000;275: 9114-9119.

16. Mignen O, Thompson JL, Shuttleworth TJ. Arachidonate-regulated $\mathrm{Ca}^{2+}$-selective (ARC) channel activity is modulated by phosphorylation and involves an A-kinase anchoring protein. $J$ Physiol 2005;567:787-798.

17. Mignen O, Thompson JL, Shuttleworth TJ. STIM1 regulates $\mathrm{Ca}^{2+}$ entry via arachidonate-regulated $\mathrm{Ca}^{2+}$-selective (ARC) channels without store depletion or translocation to the plasma membrane. J Physiol 2007;579:703-715.

18. Shuttleworth TJ. STIM and Orai proteins and the non-capacitative ARC channels. Front Biosci (Landmark Ed) 2012;17:847-860.

19. Thompson JL, Shuttleworth TJ. A plasma membrane-targeted cytosolic domain of STIM1 selectively activates ARC channels, an arachidonate-regulated store-independent Orai channel. Channels (Austin) 2012;6:370-378.

20. Deng X, Wang Y, Zhou Y, Soboloff J, Gill DL. STIM and Orai: dynamic intermembrane coupling to control cellular calcium signals. $J$ Biol Chem 2009;284:22501-22505.

21. Liao Y, Erxleben C, Abramowitz J, Flockerzi V, Zhu MX, Armstrong DL, Birnbaumer L. Functional interactions among Orai1, TRPCs, and STIM1 suggest a STIM-regulated heteromeric Orai/TRPC model for SOCE/lcrac channels. Proc Natl Acad Sci USA 2008;105: 2895-2900.

22. Zou JJ, Gao YD, Geng S, Yang J. Role of STIM1/Orai1-mediated storeoperated calcium entry in airway smooth muscle cell proliferation. $J$ Appl Physiol 2011;110:1256-1263.

23. Sathish V, Abcejo AJ, Thompson MA, Sieck GC, Prakash YS, Pabelick $\mathrm{CM}$. Caveolin-1 regulation of store-operated $\mathrm{Ca}(2+)$ influx in human airway smooth muscle. Eur Respir J 2012;40:470-478.

24. Sathish V, Abcejo AJ, VanOosten SK, Thompson MA, Prakash YS, Pabelick CM. Caveolin-1 in cytokine-induced enhancement of intracellular $\mathrm{Ca}(2+)$ in human airway smooth muscle. Am J Physiol Lung Cell Mol Physiol 2011;301:L607-L614.

25. Jia L, Delmotte P, Aravamudan B, Pabelick CM, Prakash YS, Sieck GC. Effects of the inflammatory cytokines TNF- $\alpha$ and IL-13 on stromal interaction molecule-1 aggregation in human airway smooth muscle intracellular $\mathrm{Ca}^{2+}$ regulation. Am J Respir Cell Mol Biol 2013;49: 601-608.

26. Yeung-Yam-Wah V, Lee AK, Tse FW, Tse A. Arachidonic acid stimulates extracellular $\mathrm{Ca}(2+)$ entry in rat pancreatic beta cells via activation of the noncapacitative arachidonate-regulated $\mathrm{Ca}(2+)$ (ARC) channels. Cell Calcium 2010;47:77-83.

27. Brash AR. Arachidonic acid as a bioactive molecule. J Clin Invest 2001; 107:1339-1345.

28. Kannan MS, Prakash YS, Brenner T, Mickelson JR, Sieck GC. Role of ryanodine receptor channels in $\mathrm{Ca}^{2+}$ oscillations of porcine tracheal smooth muscle. Am J Physiol 1997;272:L659-L664.

29. Putney JW Jr. Capacitative calcium entry: sensing the calcium stores. $J$ Cell Biol 2005;169:381-382.

30. Shuttleworth TJ. Orai3 - the 'exceptional' Orai? J Physiol 2012;590: 241-257.

31. Mignen O, Thompson JL, Shuttleworth TJ. Both Orai1 and Orai3 are essential components of the arachidonate-regulated $\mathrm{Ca}^{2+}$-selective (ARC) channels. J Physiol 2008;586:185-195.
32. Li WG, Yu Y, Zhang ZD, Cao H, Xu TL. ASIC3 channels integrate agmatine and multiple inflammatory signals through the nonproton ligand sensing domain. Mol Pain 2010;6:88.

33. Shuttleworth TJ. Arachidonic acid activates the noncapacitative entry of $\mathrm{Ca}^{2+}$ during $\left[\mathrm{Ca}^{2+}\right]_{i}$ oscillations. J Biol Chem 1996;271: 21720-21725.

34. Mignen O, Thompson JL, Yule DI, Shuttleworth TJ. Agonist activation of arachidonate-regulated $\mathrm{Ca}^{2+}$-selective (ARC) channels in murine parotid and pancreatic acinar cells. J Physiol 2005;564:791-801.

35. Broad LM, Cannon TR, Taylor CW. A non-capacitative pathway activated by arachidonic acid is the major $\mathrm{Ca}^{2+}$ entry mechanism in rat $A 7 r 5$ smooth muscle cells stimulated with low concentrations of vasopressin. J Physiol 1999;517:121-134.

36. Mignen O, Thompson JL, Shuttleworth $\mathrm{TJ} \mathrm{Ca}^{2+}$ selectivity and fatty acid specificity of the noncapacitative, arachidonate-regulated $\mathrm{Ca}^{2+}$ (ARC) channels. J Biol Chem 2003;278:10174-10181.

37. Mignen O, Shuttleworth TJ. Permeation of monovalent cations through the non-capacitative arachidonate-regulated $\mathrm{Ca}^{2+}$ channels in HEK293 cells: comparison with endogenous store-operated channels. J Biol Chem 2001;276:21365-21374.

38. Mignen O, Thompson JL, Shuttleworth TJ. Reciprocal regulation of capacitative and arachidonate-regulated noncapacitative $\mathrm{Ca}^{2+}$ entry pathways. J Biol Chem 2001;276:35676-35683.

39. Pabelick CM, Ay B, Prakash YS, Sieck GC. Effects of volatile anesthetics on store-operated $\mathrm{Ca}(2+)$ influx in airway smooth muscle. Anesthesiology 2004;101:373-380.

40. Parekh AB, Penner R. Store depletion and calcium influx. Physiol Rev 1997;77:901-930.

41. Putney JW Jr, McKay RR. Capacitative calcium entry channels. Bioessays 1999;21:38-46.

42. Sieck GC, White TA, Thompson MA, Pabelick CM, Wylam ME, Prakash YS. Regulation of store-operated $\mathrm{Ca}^{2+}$ entry by CD38 in human airway smooth muscle. Am J Physiol Lung Cell Mol Physiol 2008 294:L378-L385.

43. White TA, Xue A, Chini EN, Thompson M, Sieck GC, Wylam ME. Role of transient receptor potential C3 in TNF- $\alpha$-enhanced calcium influx in human airway myocytes. Am J Respir Cell Mol Biol 2006;35:243-251.

44. Prakriya M, Feske S, Gwack Y, Srikanth S, Rao A, Hogan PG. Orai1 is an essential pore subunit of the CRAC channel. Nature 2006;443: 230-233.

45. Roos J, DiGregorio PJ, Yeromin AV, Ohlsen K, Lioudyno M, Zhang S, Safrina O, Kozak JA, Wagner SL, Cahalan MD, et al. STIM1, an essential and conserved component of store-operated $\mathrm{Ca}^{2+}$ channel function. J Cell Biol 2005;169:435-445.

46. Shuttleworth TJ. Orai channels-new insights, new ideas. J Physiol 2012;590:4155-4156.

47. Chidlow JH Jr, Sessa WC. Caveolae, caveolins, and cavins: complex control of cellular signalling and inflammation. Cardiovasc Res 2010; 86:219-225.

48. Gosens R, Mutawe M, Martin S, Basu S, Bos ST, Tran T, Halayko AJ. Caveolae and caveolins in the respiratory system. Curr Mol Med 2008;8:741-753.

49. Meves $\mathrm{H}$. Arachidonic acid and ion channels: an update. $\mathrm{Br} \mathrm{J}$ Pharmacol 2008;155:4-16.

50. Barnes PJ. Biochemical basis of asthma therapy. J Biol Chem 2011; 286:32899-32905. 